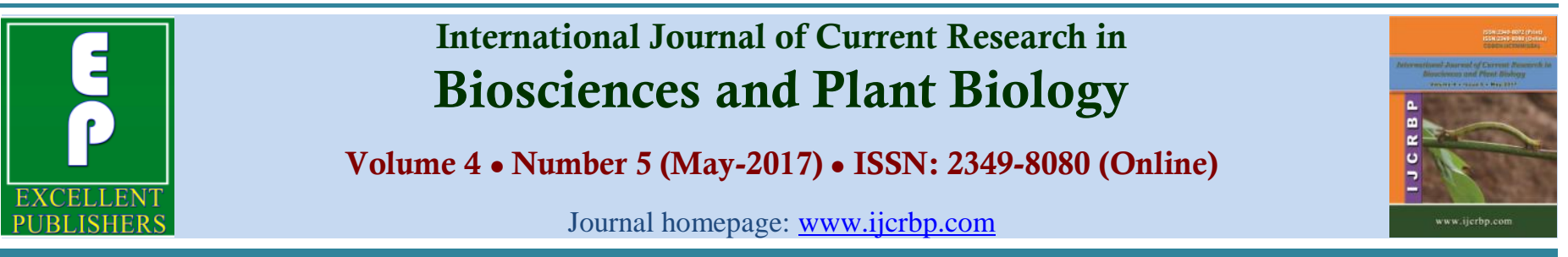

\title{
Terminator Gene Technology and Its Application in Crop Improvement
}

\author{
Ashok Kumar Malav ${ }^{1 *}$ and Arpit Gaur ${ }^{2}$ \\ ${ }^{1}$ Ph.D. Scholar, Department of Plant Breeding and Genetics, Maharana Pratap University of Agriculture and Technology, \\ Udaipur- 313 001, Rajasthan, India \\ ${ }^{2}$ Ph.D. Scholar, Department of Plant Breeding and Genetics, Chaudhary Charan Singh Haryana Agricultural University, \\ Hissar-125 004, Haryana, India
}

*Corresponding author.

\begin{tabular}{|c|c|}
\hline Abstract & Article Info \\
\hline \multirow{5}{*}{$\begin{array}{l}\text { The advances of modern plant technologies, especially genetically modified crops, are } \\
\text { considered to be a substantial benefit to agriculture and society. However, so-called } \\
\text { transgene escape remains and is of environmental and regulatory concern. Genetic use } \\
\text { restriction technologies (GURTs), developed to secure return on investments through } \\
\text { protection of plant varieties, are among the most controversial and opposed genetic } \\
\text { engineering biotechnologies as they are perceived as a tool to force farmers to depend on } \\
\text { multinational corporations' seed monopolies. In this work, the currently proposed strategies } \\
\text { are described and compared with some of the principal techniques implemented for } \\
\text { preventing transgene flow and/or seed saving, with a simultaneous analysis of the future } \\
\text { perspectives of GURTs taking into account potential benefits, possible impacts on farmers } \\
\text { and local plant genetic resources (PGR), hypothetical negative environmental issues and } \\
\text { ethical concerns related to intellectual property that have led to the ban of this technology. }\end{array}$} & $\begin{array}{l}\text { Accepted: } 24 \text { April } 2017 \\
\text { Available Online: } 06 \text { May } 2017\end{array}$ \\
\hline & Keywords \\
\hline & Genetically modified crops \\
\hline & Terminator gene \\
\hline & Traitor technology \\
\hline
\end{tabular}

\section{Introduction}

Genetic use restriction technologies (GURTs) are the name given to methods, providing specific genetic switch mechanisms that restrict the unauthorized use of genetic material (FAO, 2001) by hampering reproduction (variety-specific V-GURT) or the expression of a trait (trait-specific T-GURT) in a genetically modified (GM) plant.

\section{Variety-GURT}

It is also known as suicide/sterile seed/gene technology, or terminator technology. It is designed to control plant fertility or seed development through a genetic process triggered by a chemical inducer that will allow the plant to grow and to form seeds, but will cause the embryo of each of those seeds to produce a cell toxin that will prevent its germination if replanted, thus causing second generation seeds to be sterile and allowing manufacturers to maintain their intellectual property rights and avoid concerns related to GM seed dispersal (Lombardo, 2014).

\section{Trait-GURT}

It is considered as the second generation of V-GURT (Fisher, 2002). T-GURT (also known as traitor 
technology) is designed to switch on or off a trait (such as herbicide/cold/drought/stress tolerance, pest resistance, germination, flowering, ripening, colour, taste and nutritional qualities of the plant, defence mechanisms, or production of industrial or pharmaceutical compounds) using inducible promoters regulating the expression of the transgene through induced gene silencing (e.g., by antisense suppression) or by excision of the transgene using a recombinase (FAO, 2001). In this case, the genetic modification is activated by a chemical treatment or by environmental factors such as heat (Jefferson et al., 1999), enabling farmers to maintain the value-added traits of seeds (Eaton and van Tongeren, 2002). Both the nicknames 'terminator' and 'traitor' for these technologies were coined by the Canadian-based nongovernment organization Rural Advancement Foundation International (RAFI; today Action Group on Erosion, Technology and Concentration, ETC).

\section{Application in crop improvement}

Genetic use restriction technologies (GURTs), developed to secure return on investments through protection of plant varieties, are among the most controversial and opposed genetic engineering biotechnologies (Lombardo, 2014). GURT may be variety specific (Terminator technology) or trait specific (Traitor Technology). Traitor technology is the second generation of terminator technology with similar or near to similar mode of action (Fisher, 2002). Terminator technology on one side controls the plant fertility and the Traitor technology on the other side is designed to switch on or off of a trait, however, without killing the embryo (FAO, 2001). The genetic modification is activated by a chemical treatment or by environmental factors.

The main version of the terminator includes a set of three novel genes inserted into one plant. However, there is another version, which divides two or three genes on to two plants that are later to be crosspollinated (Oliver and Velten, 2001; Gupta 1998). The ultimate outcome is a sterile seed in the following generation. The disrupter protein may or may not be permanently active in the seed depending on the mechanism involved in V-GURT (Lombardo, 2014).

Recoverable block of function uses the barnase and barstar genes for gene flow control in transgenic plants (Kuvshinov et al., 2001). The terminator technology
Patented by Syngenta in 2001 has its implication in the vegetatively reproducing crops to increase the shelf life of the commodity during storage. Technology for selective termination of the transgenics has been developed by use of RNA interference (Lin et al., 2008). Repressible Seed Lethal System (Schernthaner et al., 2003) is a strategy based on the simultaneous insertion at the same locus on homologous chromosomes of a seed lethal gene linked to a novel trait (SL-NT) and a repressor gene (R). It ensures sterility of the seed carrying the novel trait formed by outcrossing.

T-GURT or Traitor technology may work on excision of the gene of interest (transgene) or by transfer of the transgene to subsequent generation in inactive form (Shi, 2006). The former mechanism (Zeneca patent) leads to second generation plant without the trait under consideration. The trait can be activated in the latter mechanism by application of specific chemical inducer. GM-gene-deletor system is a strategy developed to remove all functional transgenes between two recognition sequences from pollen, seeds, fruits and other edible parts of GM crops (Luo et al., 2007).

The main goal for which GURTs were designed is the technological protection of genetic resources and innovations; however, their possible application would be further useful for preventing undesired transgene flow and obtaining specific agronomic/economic benefits. Some concerns regarding these technologies have been raised. These may have negative impacts on non-target organisms and environment (Mukherjee and Senthil Kumar, 2014). Biodiversity and food security especially in developing countries that normally depend on farmsaved seed are under threat by V-GURT. Increased dependency on 'industrial' costly seeds and chemical inducers would create monopoly of companies over markets. There is risk of transgene escape (Lemaux, 2009).

T-GURTs could be received by public opinion as a favourable innovation as they would allow farmers to decide for activation of valuable trait without impeding plant viability and traditional conservation practices. The ethical concerns against V-GURTs that led to the global moratorium remain to date too strong to overcome and will surely play a pre-eminent role in the future political debate to decide whether to use or not use these technologies. 


\section{Views of farmer's upon terminator gene}

Farmer's organizations across India have demanded a ban on any seed material containing the terminator gene.

1. Questions on the ethical and social relevance of the technology in a country like India were farming in the major occupation.

2. There is the danger of this technology affecting the unintended targets, through pollen transfer.

3. The seed is used for consumption it may cause health hazards due to treatment of the seed with chemicals (or) toxins.

4. The country's rich genetic biodiversity will be lost. Maximum crop field may be covered by just one genotype, and it will eliminate the farm conservation traditions and location specific varieties.

5. The impact of tetracycline soaked seeds on soil ecology, particularly on microflora and fauna will be dangerous.

\section{Advantages}

1. This technology will induce private sector to make more investment in research and development of pure line varieties and open pollinated varieties because in these varieties the farmers do not change the seeds each years.

2. Farmers will use new seeds every year leads to maximum production.

3. This will result in stiff competition between the public and private sector institutions and ultimately the farmers will benefit through this technology.

\section{Conclusion}

It is difficult to predict the development of GURTs in the near future because they seem still to be very far from commercialization. T-GURTs could be received by public opinion as a favourable innovation as they would allow farmers to decide for activation of valuable trait. T-GURTs would not impede plant viability and would not affect the traditional conservation practices and exchange of seeds, offering at the same time a solution to the problem of genetic pollution by preventing the spread of the engineered traits.

In contrast, the ethical concerns against V-GURTs that led to the global moratorium remain to date too strong to overcome and will surely play a pre-eminent role in the future political debate to decide whether to use or not use these technologies. After all, over one billion people, the majority of whom live in developing countries, depend on seed saving and exchanging of seeds with their neighbours, whereas these technologies are conceived (and perceived) as a means to protect multinational corporations and their patents.

\section{Conflict of interest statement}

Authors declare that they have no conflict of interest.

\section{References}

Eaton, D.J.F., van Tongeren, F.W., 2002. Potential Economic Impacts of GURT Technologies at National and International Levels. 48 p.

FAO, 2001. Potential Impacts of Genetic Use Restriction Technologies (GURTs) on Agricultural Biodiversity and Agricultural Production Systems. Wageningen University Research Centre. The Netherlands.

Fisher, W.W., 2002. The impact of terminator gene technologies on developing countries. In: Biotechnology, Agriculture, and the Developing World (Ed.: Swanson, T.). Edward Elgar Publishing. pp.137-149.

Gupta, P. K., 1998. The terminator technology for seed production and protection: why and how? Curr. Sci. 75, 1319-1323.

Jefferson, R.A., Byth, D., Correa, C., Otero, G., Qualset, C., 1999. Genetic use restriction technologies: Technical assessment of the set of new technologies which sterilize or reduce the agronomic value of second generation seed, as exemplified by U.S. Patent No. 5,723,765, and WO 94/03619.

Kuvshinov, V., Koivu, K., Kanerva, A., Pehu, E., 2001. Molecular control of transgene escape from genetically modified plants. Plant Sci. 160, 517-522.

Lemaux, P. G., 2009. Genetically engineered plants and foods: A scientist's analysis of the issues (Part II). Annu. Rev. Plant Biol. 60, 511-559.

Lin, C., Fang, J., Xu, X., Zhao, T., Cheng, J., Tu, J., Ye, G., Shen, Z., 2008. A built-in strategy for containment of transgenic plants: creation of selectively terminable transgenic rice. PlosOne. 3, e1818.

Lombardo, L., 2014. Genetic use restriction technologies: A review. Plant Biotechnol. J. 12, 995-1005. 
Luo, K., Duan, H., Zhao, D., Zheng, X., Deng, W., Chen, Y., Stewart, C.N.Jr., McAvoy, R., Jiang, X., Wu, Y., He, A., Pei, Y., Li, Y., 2007. GM-genedeletor: fused lox P-FRT recognition sequences dramatically improve the efficiency of FLP or CRE recombinase on transgene excision from pollen and seed of tobacco plants. Plant Biotechnol. J. 5, 263274.

Mukherjee, S., Senthil Kumar, S., 2014. Terminator gene technology - their mechanism and consequences. Science Vision. 14, 51-58.

Oliver, M.J., Velten, J., 2001. Development of a genetically based seed technology protection system. In: Dealing with Genetically Modified Crops (Eds.: Wilson, R.F., Hou, C.T., Hildebrand, D.F.). AOCS Press, Champaign, IL. pp.110-114.

Schernthaner, J. P., Fabijanski, S.F., Arnison, P.G., Racicot, M., Robert, L.S., 2003. Control of seed germination in transgenic plants based on the segregation of a two-component genetic system. Proc. Nat. Acad. Sci. (USA). 100, 6855-6859.

Shi, G., 2006. Intellectual Property Rights, Genetic Use Restriction Technologies (GURTs), and Strategic Behavior. American Agricultural Economics Association Annual Meeting. Long Beach, California.

\section{How to cite this article:}

Malav, A.K., Gaur, A., 2017. Terminator gene technology and its application in crop improvement. Int. J. Curr. Res. Biosci. Plant Biol. 4(5), 57-60. doi: https://doi.org/10.20546/ijcrbp.2017.405.007 